\title{
BACTERIAL GROWTH AND DOC CONSUMPTION IN A TROPICAL COASTAL LAGOON
}

\author{
FARJALLA, V. F. ${ }^{1}$, ENRICH-PRAST, A. ${ }^{1}$, ESTEVES, F. A. ${ }^{1}$ and CIMBLERIS, A. C. P. ${ }^{2}$ \\ ${ }^{1}$ Laboratório de Limnologia, Departamento de Ecologia, Instituto de Biologia, CCS, UFRJ, \\ C. P. 68020, CEP 21941-590, Rio de Janeiro, RJ, Brazil \\ ${ }^{2}$ FURNAS Centrais Elétricas S. A., Departamento de Meio Ambiente, Rua Real Grandeza, 219, \\ CEP 22283-900, Rio de Janeiro, RJ, Brazil \\ Correspondence to: Vinicius Fortes Farjalla, Laboratório de Limnologia, Departamento de Ecologia, \\ Instituto de Biologia, CCS, UFRJ, C. P. 68020, CEP 21941-590, Rio de Janeiro, RJ, Brazil, \\ e-mail: farjalla@biologia.ufrj.br \\ Received May 26, 2003 - Accepted June 14, 2004 - Distributed May 31, 2006
}

(With 4 figures)

\begin{abstract}
The aims of this research were to determine the main limiting nutrient to bacterial growth in Imboassica lagoon, southeastern Brazil, to estimate the percentage of dissolved organic carbon (DOC) available for bacterial growth, and to determine the bacterial growth efficiency (BGE) of natural assemblages. Bacterial growth and DOC consumption were determined in batch culture experiments, in which water samples were supplemented with nitrogen and phosphorus together or separately, or incubated without nutrient additions. When added together, $\mathrm{N}$ and $\mathrm{P}$ stimulated higher bacterial growth rates and production, as well as higher DOC consumption. The BGEs and DOC consumption rates were strongly dependent on the method used to determine bacterial production. The BGE ranged from 11 to $72 \%$. However, only a minor fraction of bulk DOC was consumed by the planktonic bacteria (from 0.7 to $3.4 \%$ ). The results suggest that low availability of phosphorus and nitrogen coupled with excess organic carbon was the main factor responsible for the relatively low bacterial utilization of DOC in Imboassica lagoon.
\end{abstract}

Keywords: bacterioplankton, DOC consumption, BGE, coastal lagoons, phosphorus and nitrogen colimitation.

\section{RESUMO}

\section{Crescimento bacteriano e consumo de COD em uma lagoa costeira tropical}

Os objetivos desta pesquisa foram: determinar o principal nutriente limitante ao crescimento bacteriano na lagoa Imboassica, estimar a porcentagem de Carbono Orgânico Dissolvido (COD) disponível para o crescimento bacteriano e determinar a Eficiência de Crescimento Bacteriano (ECB) da comunidade bacteriana. $\mathrm{O}$ crescimento bacteriano e o consumo de COD foram avaliados em experimentos de culturas de diluição, nos quais nitrogênio e fósforo foram adicionados às amostras de água, juntos ou separadamente, e um controle foi preparado sem adições de nutrientes. Quando adicionados juntos, N e P estimularam um maior crescimento e produção bacterianos, assim como maiores taxas de consumo de COD. ECB e taxas de consumo de COD foram fortemente dependentes do método utilizado para determinar a produção bacteriana. ECB variou de $11 \%$ a $72 \%$, porém apenas uma pequena fração do COD total foi consumida pelas bactérias planctônicas (de 0,7\% a 3,4\%). Sugere-se que as baixas disponibilidades de fósforo e nitrogênio são os principais fatores responsáveis pela baixa utilização de COD pelas bactérias na lagoa Imboassica.

Palavras-chave: bacterioplâncton, consumo de COD, eficiência do crescimento bacteriano, lagoas costeiras, colimitação por fósforo e nitrogênio. 


\section{INTRODUCTION}

Dissolved organic carbon (DOC) is the main carbon stock in aquatic ecosystems. Globally, more organic matter occurs in dissolved form in seawater than in all land plants and marine organisms combined (Hedges \& Keil, 1995). Low DOC concentrations are usually found in open ocean and in large lakes, while high DOC concentrations are observed in humic lakes and swamps. Several tropical lagoons of the Atlantic coast of Rio de Janeiro State have high DOC concentrations (Farjalla et al., 2001), comparable only to the DOC concentration of freshwater swamps (Bano et al., 1997). However, few studies related to DOC utilization in tropical coastal lagoons have been published.

For several decades DOC was considered to be biologically inert, and its loss from aquatic ecosystems was attributed to oxidation, sedimentation, and complexion with metals (Perdue, 1998). More recent observations have shown that bacteria can scavenge DOC with high efficiency and convert DOC into bacterial biomass, via bacterial production, or into $\mathrm{CO}_{2}$, via respiration (Ducklow, 1994). Bacterial growth efficiency (BGE), i.e., the ratio of bacterial biomass produced to substrate consumed, is an important measurement used to understand DOC flux through aquatic trophic chains and DOC amounts released as $\mathrm{CO}_{2}$ into the atmosphere (Søndergaard \& TheilNielsen, 1997). Recent estimates have shown that BGE often falls within the range of 20 to $60 \%$ at natural DOC concentrations in freshwater, estuarine and marine ecosystems (del Giorgio et al., 1997; Søndergaard, 1997). Lower and higher BGE values were also observed in waters having low-quality DOC, and for bacterial degradation of aquatic macrophytes and phytoplanktonic debris (Cole \& Pace, 1995; Søndergaard, 1997).

Coastal lagoons are relatively shallow lakes occuring near the ocean, from which they are partially or entirely sealed off by sand bars built by tidal or wave action (Branco et al., 2000). Due to their proximity to the ocean, Brazilian coastal lagoons are often surrounded by cities and used as harbors, recreational areas, fisheries, or for sewage disposal and landfills (Esteves, 1998). In the present study, we estimated bacterial production, abundance, biomass, and BGE in the water column of a typical tropical coastal lagoon, the Imboassica, in Rio de Janeiro state. The objectives were 1) to determine the main limiting nutrient for bacterial growth; 2) to estimate available DOC to bacterial growth in the lagoon's waters; and 3) to determine $\mathrm{BGE}$ of its natural assemblages.

\section{MATERIALS AND METHODS}

\section{Study area}

Imboassica lagoon, which is located on a coastal plain $\left(22^{\circ} 50^{\prime} \mathrm{S} ; 44^{\circ} 42^{\prime} \mathrm{W}\right)$ in northern Rio de Janeiro State, Brazil (Fig. 1), was formed when the Imboassica River was dammed by a sand bar formed by wave action on the ocean shoreline (Esteves, 1998). A shallow lagoon, it has a maximum $2.1 \mathrm{~m}$ depth and an area of $c a$. 326 ha (Panosso \& Esteves, 1999). Regional climate is warm and humid, presenting annual averages of $26.6{ }^{\circ} \mathrm{C}$ in temperature and $1,500 \mathrm{~mm}$ in precipitation. Approximately one third of the lagoon is shallow and presents dense aquatic plant growth (Fig. 1). This area is extensively colonized by aquatic macrophytes, e.g., Typha domingensis and Eleocharis mutata (Palma-Silva, 1999).

\section{Experimental design}

In June 1998, water from the central portion of Imboassica lagoon was collected in $20 \mathrm{~L}$ plastic bottles previously rinsed with filtered water. They were immediately transported to the laboratory, and samples of initial DOC concentration, bacterial abundance, and bacterial biomass were collected and preserved for later estimations.

The complete experimental setup is described in previous works (Cimbleris \& Kalff, 1998; Farjalla et al., 2002). In the laboratory, water was passed through a pore size $0.2 \mu \mathrm{m}$ filter (SuporCap 100, Gelman Sciences) to remove bacteria. An inoculum was prepared by passing lake water through a GF/F filter (pore size $0.8 \mu \mathrm{m}$, Whatman) to remove large particulate matter from the water. To minimize organic and inorganic contamination from filters, we flushed the filters with approximately $1 \mathrm{~L}$ of lake water sample before filtrate collection. Bacteria were cultivated by combining $90 \%$ of $0.2 \mu \mathrm{m}$ filtered lake water and $10 \%$ of inoculum. The filtered lake water and inoculum were poured into acid-rinsed $(\mathrm{HCl} 10 \%)$, heat-sterilized $\left(120{ }^{\circ} \mathrm{C}, 1 \mathrm{~atm}\right.$ autoclavation pressure) $200 \mathrm{~mL}$ 


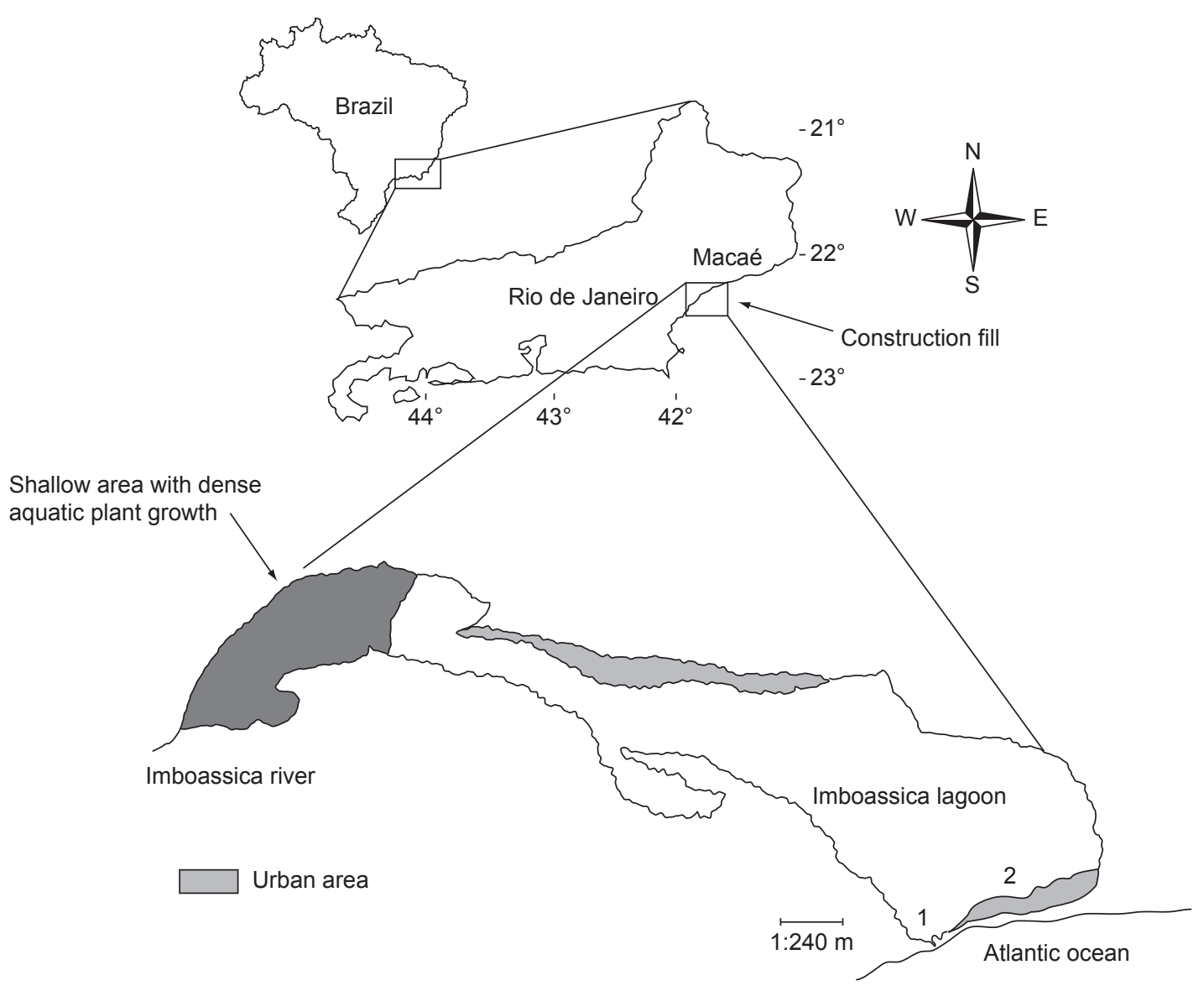

Fig. 1 - Map indicating location of Imboassica lagoon, Macaé, Rio de Janeiro, Brazil.

glass flasks. These cultures were used to determine bacterial abundance, biomass, and production. The filtered lake water and inoculum were also put in $60 \mathrm{~mL}$ Winkler glass flasks, leaving no headspace, to measure bacterial respiration. The complete process generally took $6-8 \mathrm{~h}$.

Four sets of experiments, each replicated four times, were performed: 1) control treatment: culture incubated without nutrient additions; 2) $\mathrm{N}$ treatment: culture incubated with addition of $\mathrm{NH}_{4} \mathrm{NO}_{3}(50 \mu \mathrm{M}-\mathrm{N})$; 3) $\mathrm{P}$ treatment: culture incubated with addition of $\mathrm{KH}_{2} \mathrm{PO}_{4}(5 \mu \mathrm{M}-\mathrm{P})$; and 4) NP treatment: culture incubated with addition of $\mathrm{NH}_{4} \mathrm{NO}_{3}$ and $\mathrm{KH}_{2} \mathrm{PO}_{4}$ together $(50 \mu \mathrm{M}-\mathrm{N}$ and $5 \mu \mathrm{M}-\mathrm{P})$. The cultures were incubated in the dark at room temperature; bacterial growth was followed by measurements after 24,48 , and $72 \mathrm{~h}$ of bacterial production, abundance, biomass, and respiration.

We measured bacterial production in water cultures by two methodologies, the first of which is based on the incorporation of ${ }^{3} \mathrm{H}$-leucine by bacteria (Smith \& Azam, 1992), and the other based on bacterial biomass increase over time in the cultures. In the latter case, bacterial biomass was obtained through the conversion of bacterial biovolume by two different factors: $308 \mathrm{fg} \mathrm{C} \mu \mathrm{m}^{-3}$

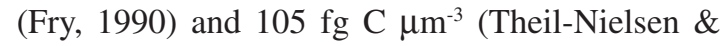
Søndergaard, 1998).

Bacterial respiration was estimated by the Winkler method based on dissolved oxygen consumption, which was converted to respired bacterial carbon using a respiratory quotient of 1.0. 
Bacterial growth efficiency (BGE) was calculated during the growth phase, as $\mathrm{BP} /(\mathrm{BP}+\mathrm{BR})$, where $\mathrm{BP}$ is the bacterial production rate and $\mathrm{BR}$, the bacterial respiration rate (Søndergaard \& TheilNielsen, 1997). The DOC bioavailability was calculated as follows: $\mathrm{DOC}_{\mathrm{L}}=\left(\mathrm{DOC}_{\mathrm{B}}+\mathrm{DOC}_{\mathrm{R}}\right)$ $/ \mathrm{DOC}_{\mathrm{T}}$, where $\mathrm{DOC}_{\mathrm{L}}$ is labile $\mathrm{DOC}$ for bacteria, $\mathrm{DOC}_{\mathrm{B}}$ is dissolved organic carbon converted into bacterial biomass, $\mathrm{DOC}_{\mathrm{R}}$ is dissolved organic carbon respired by bacteria, and $\mathrm{DOC}_{\mathrm{T}}$ is initial DOC bulk.The DOC bioavailability was estimated during log phase (Carlson \& Ducklow, 1996).

\section{Analytical methods}

Bacterial abundance was measured using a Beckton Dickinson FACSort flow-cytometer, according to methodology proposed by del Giorgio et al. (1996). Syto 13 stain $(50 \mu \mathrm{M}$, Molecular Probes) and Fluoresbrite ${ }^{\mathrm{TM}}$ Carboxy YG Microspheres $\left(\varnothing=1.58 \mu \mathrm{m}, c a .3 \times 10^{5} \mathrm{~mL}^{-1}\right.$, Polysciences) were added to $1 \mathrm{~mL}$ subsamples. The cytometer was controlled with CellQuest 1.2 software. Bacterial cells and microspheres were separated in a log-log scattergram of green fluorescence intensity (FL1) and side scattering (SSC). Samples were run for one minute or until 10,000 cells were counted. Bacterial abundance in the samples was calculated using as an internal standard microspheres, the number of which in standard stock solution was analyzed by epifluorescence microscopy. Bacterial biomass was estimated by measuring bacterial biovolume in an epifluorescence microscope connected to a video camera with an image analysis system. Bacteria samples were previously stained with DAPI, according to Porter and Feig (1980). Images were captured with Image Grabber-24 software (Neotech) and processed with IPLab Spectrum 3.1a software (Signal Analytics). At least 150 bacteria on 3 images were measured in each sample; cell volume was calculated using a formula proposed by Fry (1990). The previously mentioned conversion

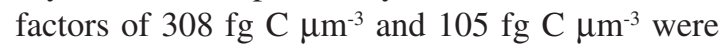
used to convert bacterial biovolume to bacterial biomass.

Bacterial secondary production in these cultures was obtained through the increase in bacterial biomass (see method above) or from the incorporation of ${ }^{3} \mathrm{H}$-leucine (Smith \& Azam, 1992). For ${ }^{3} \mathrm{H}$-leucine incorporation, $1.3 \mathrm{~mL}$ of the culture was incubated in Eppendorf ${ }^{\circledR} 1.5 \mathrm{~mL}$ tubes containing $20 \mathrm{nM}$ of ${ }^{3} \mathrm{H}$-leucine (5-fold diluted solution, $159 \mathrm{Ci} \mathrm{mmol}^{-1}$, Amersham), at room temperature in the dark for $45 \mathrm{~min}$. A control was prepared for each culture by adding $90 \mu \mathrm{l}$ of TCA $(100 \%)$ to an identical tube. After incubation, $90 \mu \mathrm{l}$ of TCA (100\%) was also added to each of the replicates to stop the reaction. Each tube was washed sequentially with 5\% TCA and $80 \%$ ethanol. Five hundred $\mu \mathrm{l}$ of scintillation cocktail (Aquasol 2, Dupont) was added to each tube and radioactivity measured using a Beckman LS-5600 Liquid Scintillation System. Bacterial production was calculated assuming an intracellular leucine dilution factor equal to two; and a cellular carbonto-protein ratio equal to 0.86 (Wetzel \& Linkens, 1991).

A Shimadzu Carbon Analyzer TOC-5000 was used to measure DOC concentrations, with DOC ascertained by subtracting from the carbon total the DIC, which was measured by an infrared sensor through acidifying inorganic forms of carbon to $\mathrm{CO}_{2}$. At least three DOC and DIC measurements were made for each sample, resulting in a coefficient of variation $(\mathrm{CV})$ of less than $2 \%$. Dissolved nitrogen concentration was obtained through digestion at $320{ }^{\circ} \mathrm{C}$ and distillation of the $\mathrm{NH}_{4}^{+}$formed (Mackereth et al., 1978). Dissolved phosphorus was measured by autoclaving and formation of ammonium molybdate (Golterman et al., 1978). Chlorophyll $a$ was extracted with $90 \%$ ethanol, measured by absorbance at $665 \mathrm{~nm}$ and corrected for turbidity at $750 \mathrm{~nm}$ (Nusch \& Palme, 1975). Absorbance at $430 \mathrm{~nm}$ was used to estimate Imboassica water-sample color.

\section{Statistics}

Differences among control, N, P, and NP treatments were tested by one-way ANOVA, followed by a Tuckey post-hoc test, according to Zar (1996). A probability level of $\alpha=0.05$ was used throughout to determine statistical significance.

\section{RESULTS}

Water $\mathrm{pH}(8.16)$ and salinity $(6.0 \%)$ of Imboassica lagoon were relatively high, showing the influence of the neighboring ocean. We also observed a high DOC concentration $(1.06 \mathrm{mM} \mathrm{C})$ and, consequently, high $\mathrm{C}: \mathrm{N}: \mathrm{P}$ molar ratio 
(2078:12:1). On the other hand, the lagoon had a low transparency $(0.6 \mathrm{~m})$ that, however, was not due to its water color (Abs 0.008 at $430 \mathrm{~nm}$ ), but probably because of the moderately high chlorophyll $a$ values $\left(8.11 \mu \mathrm{gL}^{-1}\right)$.

Bacterial abundance in Imboassica lagoon was around $3.4 \times 10^{9}$ bacteria $\mathrm{L}^{-1}$, representing a $2.4 \mu \mathrm{M} \mathrm{C}$ bacterial biomass. Initial bacterial production was $0.032 \mu \mathrm{M} \mathrm{Ch}^{-1}$. Calculation showed that approximately 3 days would be adequate for the bacterial population to double its biomass in the lagoon.

Control, N, P, and NP cultures demonstrated a classic sigmoidal growth curve (Fig. 2). Cultures were initiated with approximately $3.5 \times 10^{8}$ cells L $^{-1}$ and reached the stationary phase after 2-3 days. After $72 \mathrm{~h}$, the NP treatment reached the highest bacterial abundance of $4.2 \times 10^{9}$ cells $\mathrm{L}^{-1}$, and also showed the only bacterial growth ratio significantly higher (ANOVA, $\mathrm{p}<0.05$ ) than those obtained in the other three treatments. The second highest bacterial abundance $\left(2.7 \times 10^{9}\right.$ cells $\left.\mathrm{L}^{-1}\right)$ occurred in the $\mathrm{P}$ treatment, which approximated the final bacterial abundance observed for both control and $\mathrm{N}$ treatments $\left(2.1 \times 10^{9}\right.$ cells $\left.\mathrm{L}^{-1}\right)$. No significant increase was observed in bacterial biovolume during the logarithmic and stationary phases in any of the treatments (ANOVA, p < 0.05, Fig. 3).

Bacterial secondary production was measured in all treatments by ${ }^{3} \mathrm{H}$-leucine incorporation

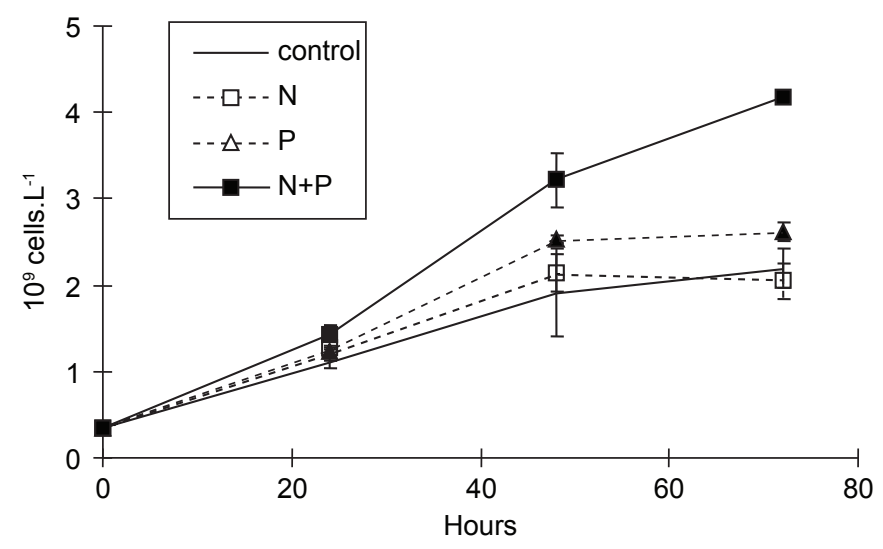

Fig. 2 - Bacterial growth curves in Imboassica water cultures. Bars $=S D, n=4$.

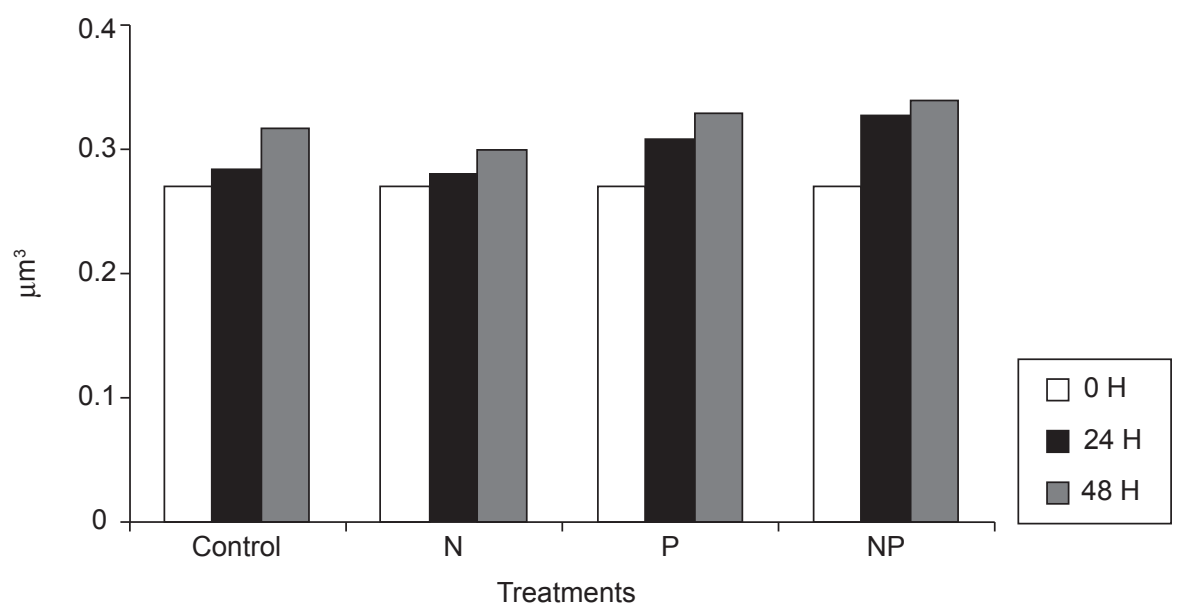

Fig. 3 - Bacterial biovolume changes during bacterial growth in Imboassica cultures. 
(Fig. 4) and by bacterial biomass increase, using the bacterial biovolume-biomass conversion factors

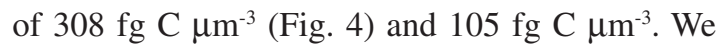
observed an increase in the bacterial production rate in all treatments measured by changes in bacterial biomass during the logarithmic phase (from 0 to 48 h; Fig. 4a). On the other hand, a decrease in all treatments in bacterial production rates occurred from the middle $(24 \mathrm{~h})$ to the end of logarithmic phase $(48 \mathrm{~h})$ as measured by incorporation of ${ }^{3} \mathrm{H}$ leucine. These decreases occurred independently of the increase in bacterial abundance (Fig. 4b).

While the lower bacterial production rates were found using the ${ }^{3} \mathrm{H}$-leucine method, the higher were found using the bacterial biomass method, obviously with the higher conversion factor, i.e.,

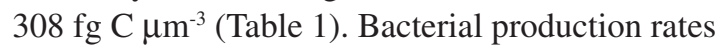

ranged from 0.027 to $0.535 \mu \mathrm{M} \mathrm{C} \mathrm{h}^{-1}$, with higher rates in the NP treatments and the lower rates in the control and $\mathrm{N}$ treatments (Table 1).

Bacterial respiration varied from 0.119 to $0.212 \mu \mathrm{M} \mathrm{C}$ in control and NP treatments, respectively. The DOC consumed throughtout the logarithmic growth phase ranged from 0.7 to $3.4 \%$, depending on the bacterial production method used (Table 1). Consumption was higher in the NP treatment, followed by $\mathrm{P}, \mathrm{N}$, and control treatments. The BGE ranged from 11 to $72 \%$ and, as previously mentioned, was strongly influenced by the bacterial production method (Table 1). Higher BGE values were usually found for control and NP cultures, while lower ones generally resulted from the $\mathrm{N}$ treatment (Table 1). During incubations temperature was maintained at around $24{ }^{\circ} \mathrm{C}$.
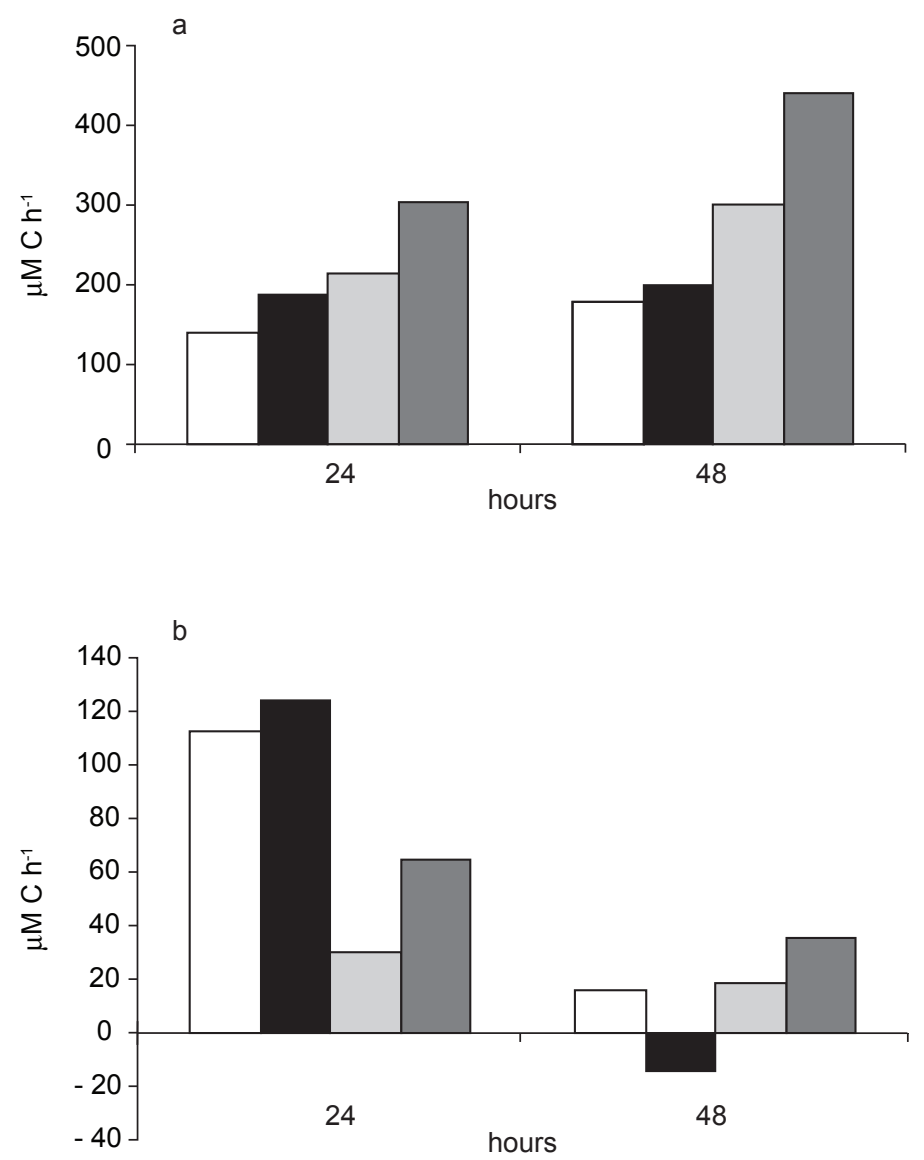

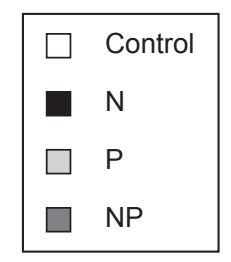

Fig. 4 - Percentage of change in bacterial production rate in relation to incubation initiation: a) bacterial production meas-

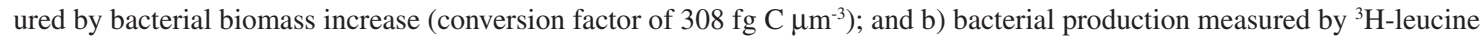
incorporation. 
TABLE 1

Bacterial production rate, bacterial respiration rate, DOC consumed, and bacterial growth efficiency in Imboassica water cultures.

\begin{tabular}{|l|c|c|c|c|c|c|c|c|c|c|}
\hline Treatments & \multicolumn{3}{|c|}{ BP rate $\left(\mu \mathbf{M ~ C ~}^{-1}\right)$} & \multicolumn{3}{c|}{$\begin{array}{c}\text { BR rate } \\
\left(\mu \mathbf{M ~ C ~ h}^{-1}\right)\end{array}$} & \multicolumn{3}{c|}{$\begin{array}{c}\text { DOC } \\
\text { consumed (\%) }\end{array}$} & \multicolumn{3}{c|}{ BGE (\%) } \\
\hline & A & B & C & & A & B & C & A & B & C \\
\hline Control & 0.037 & 0.107 & 0.275 & 0.119 & 0.7 & 1.0 & 1.8 & 24 & 47 & 70 \\
\hline N & 0.027 & 0.115 & 0.294 & 0.212 & 1.1 & 1.5 & 2.3 & 11 & 35 & 59 \\
\hline P & 0.037 & 0.154 & 0.394 & 0.190 & 1.0 & 1.6 & 2.6 & 17 & 45 & 67 \\
\hline NP & 0.043 & 0.209 & 0.535 & 0.212 & 1.2 & 1.9 & 3.4 & 17 & 50 & 72 \\
\hline
\end{tabular}

A) Bacterial production rate (BP), DOC consumed, and BGE estimated from ${ }^{3} \mathrm{H}$ - leucine incorporation at the end of logarithmic phase; B) Bacterial production rate (BP), DOC consumed, and BGE estimated from bacterial biomass increase during the logarithmic phase. Biomass (Theil-Nielsen \& Søndergaard, 1998) = (abundance $\mathrm{x}$ mean cell volume) $\mathrm{x} 105 \mathrm{fg} \mathrm{C} \mathrm{mm}^{-3}$; and C) Bacterial production rate (BP), DOC consumed, and BGE estimated from bacterial biomass increase during the logarithmic phase. Biomass $\left(\right.$ Fry 1990) $=($ abundance $\mathrm{x}$ mean cell volume $) \times 308 \mathrm{fg} \mathrm{C} \mu \mathrm{m}^{-3}$.

\section{DISCUSSION}

Duetoitslocation, Imboassicalagoonissubject to two severe types of anthropogenic impacts, the first of which occurs with the opening of the sand bar separating the lagoon from the ocean. This not only alleviates pollution by draining lagoon waters, but also allows access by ocean fish in incoming waters. The second impact is the domestic effluent release directly into the lagoon. Whereas the high salinity and, consequently, high $\mathrm{pH}$ observed in this lagoon is related to the last sand bar opening in March 1998, its cultural eutrophication - caused by sewage disposal - stimulates phytoplankton growth and, consequently, the relatively high chlorophyll $a$ values $\left(8.11 \mu \mathrm{g} \mathrm{Chl} a \mathrm{~L}^{-1}\right.$ ) in its water column (see Melo, 2001). In contrast, thirteen other relatively unpolluted tropical coastal lagoons in Rio de Janeiro State have an average of $3.65 \mu \mathrm{g} C h l a \mathrm{~L}^{-1}$ (Farjalla et al., 2001).

The observed initial bacterial abundance (3.4 X $10^{9}$ cells $\left.\mathrm{L}^{-1}\right)$, biomass $(2.4 \mu \mathrm{M} \mathrm{C})$, and secondary productivity $\left(0.032 \mu \mathrm{M} \mathrm{Ch}^{-1}\right)$ are within the range of most tropical freshwater ecosystems (Torréton et al., 1994; Benner et al., 1995; Lindell \& Edling, 1996; Anesio et al., 1997; Thomaz \& Esteves, 1997; Bouvy et al., 1998). Direct disposal of sewage into Imboassica lagoon, although stimulating phytoplankton growth (Melo, 2001), has not resulted in higher bacterial abundance, biomass, and secondary productivity than that found in other, less impacted Brazilian tropical coastal lagoons (Farjalla et al., 2001; Farjalla et al., 2002). According to Bratbak and Thingstad (1985), phytoplankton competes with bacteria for phosphorus supplies. In clear-water ecosystems with high light availability, phytoplankton is more capable than bacteria of scavenging phosphorus. Moreover, bacterial-algal competition seems to be less favorable to bacteria as lake entrophy increases (Vadstein \& Olsen, 1989; Currie, 1990). Therefore, in Imboassica lagoon, that sewage disposal did not result in marked increases in bacterial biomass might be due to the competition between phytoplankton and bacteria for the phosphorus supply. Nitrogen may also be a limiting factor for bacterial growth. Experiments in a eutrophic reservoir showed an increase in bacterial growth and production when surface water was supplemented with ammonium (Wang et al., 1992). Furthermore, bacterial abundance in a mesoeutrophic lake was only significantly correlated to Chl $a$ following ammonium nitrate additions, implying that both bacteria and phytoplankton were mutually influenced by the $\mathrm{N}$ supply (Le et al., 1994).

Bacterial populations in aquatic ecosystems can be regulated by several factors, divisible into bottom-up factors (e.g., nutrient concentrations and temperature), which are generally considered the main regulators of bacterial community in aquatic ecosystems, or top-down factors, e.g., grazing by zooplankton and viral lysis (Pace \& Cole, 1994; Pace \& Cole, 1996). Microbial growth requires a balanced supply of organic carbon and nutrients (Neidhardt et al., 1990). In Imboassica lagoon, 
bacteria are limited by availability of phosphorus and nitrogen, since those nutrients when added together significantly stimulated bacterial growth in cultures (Fig. 2). The high C:N:P ratio of 2078:12:1, compared to the actual content of carbon, nitrogen, and phosphorus in bacteria (50:10:1, Fagerbakke et al., 1996), further corroborates bacterial growth as being colimited by phosphorus and nitrogen in Imboassica lagoon.

That chlorophyll $a$ concentrations, in relation to those of less impacted coastal lagoons, are relatively high in Imboassica lagoon suggests that in it phytoplankton is an important DOC source. Other important sources are the large aquatic macrophytes beds surrounding the lagoon and the raw sewage input. The DOC from phytoplankton exudates and that leached from macrophytes, both considered biologically labile, are readily available to bacteria (Baines \& Pace, 1991; Carlson \& Ducklow, 1996; Mann \& Wetzel, 1996).

The DOC assimilated by bacteria may be converted to respiratory $\mathrm{CO}_{2}$ or be transformed into bacterial biomass. We observed not only bacterial abundance and biovolume increases in our cultures (Figs. 2 and 3), but also an increase in respiration following nutrient additions (Table 1). Therefore, BGE did not necessarily increase in nutrient-enriched water because respiratory losses also increased. It has actually been shown that bacteria can dissociate catabolic and anabolic processes, i.e., there is no obligatory coupling between respiration and growth and, consequently, BGE is theoretically highly variable (Middelboe \& Søndergaard, 1993).

We used two methods in estimating bacterial production in Imboassica cultures. The first method, which results in instantaneous bacterial production measurement, is based on bacterial incorporation of labeled leucine in 0,24 , and $48 \mathrm{~h}$ of bacterial growth; the other method is based on bacterial biomass increase throughout the growth phase in the cultures (from 0 to $48 \mathrm{~h}$ ). In the first case, decrease in bacterial production from 24 to $48 \mathrm{~h}$ (Fig. 4b) should be related to a decrease in bacterial metabolism between 24 and $48 \mathrm{~h}$ and is independent of bacterial abundance increase. Bacterial production based on bacterial biomass increase is an integrated analysis of the entire bacterial growth in the cultures. However, it is strongly dependent on the conversion factor used (Table 1, columns b and c).

When considering bacterial biomass increase, Imboassica cultures showed high BGE values (Table 1, column c) compared to cultures in other lake water (see Søndergaard \& Theil-Nielsen, 1997) and coastal systems (Toolan, 2001). Several studies in the literature have focused on determining bacterial biovolume-biomass conversion factors, based on direct measurement of bacterial carbon content, on natural bacteria growth in natural conditions, and on bacteria growth in cultures (Watson et al., 1977; Bratbak, 1985; Bjørnsen, 1986; Norland et al., 1987; Fry, 1990; Carlson \& Ducklow, 1996; Theil-Nielsen \& Søndergaard, 1998). These studies have yielded a wide spectrum of conversion factors varying from 105 to $560 \mathrm{fg} \mathrm{C} \mu \mathrm{m}^{-3}$. We used conversion factors suggested by Fry (1990) and Theil-Nielsen and Søndergaard (1998). The Fry factor (308 fg C $\mu^{-3}$ ) has already been widely used in previous studies, while the Theil-Nielsen and Søndergaard factor (105 $\mathrm{fg} \mathrm{C} \mathrm{mm}^{-3}$ ) is particularly suited to our circumstances, as it was based on bacterial growth in freshwater and marine cultures. According to Norland et al. (1987), the expected carbon content of a bacterial cell with a $0.27 \mu \mathrm{m}^{-3}$ biovolume, which was usually observed in our batch cultures (Fig. 3), would imply a conversion factor of lower than

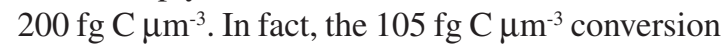
factor, as well as the ${ }^{3} \mathrm{H}$-leucine incorporation method, produced $\mathrm{BGE}$ values within a range observed in recent estimates (Toolan, 2001). Furthermore, our respiration rates were similar to those reported in the literature.

Bacteria in Imboassica cultures consumed only a minor DOC fraction, regardless of the bacterial production method used, and the high DOC concentration suggests a DOC accumulation in Imboassica lagoon (Table 1).Zweifel et al.(1995) observed a net DOC accumulation in the Bothnian Sea coastal areas, where bacterial community growth was limited by the phosphorus supply. In addition, DOC may accumulate if bacterial growth rates remain low due to competition with algae for inorganic nutrients (Thingstad et al., 1997). Given nutritional environments largely determine substrate utilization by bacteria, as demonstrated by physiological studies which exhibit an order of magnitude energy-cost savings in biosynthesis 
of cellular components, notably protein and nucleotides, when bacteria grow in a rich medium (Neidhardt et al., 1990). Furthermore, plant decomposition rates correlate positively to nitrogen and phosphorus concentrations (Enríquez et al., 1993). Likewise, DOC biodegradability increases upon N (Kirchman et al., 1991) and P (Pomeroy et al., 1995) additions in oceanic waters, and by supplementation by both in estuarine waters (Coffin et al., 1993). Bacteria doubled DOC scavenging in Imboassica cultures after simultaneously adding phosphorus and nitrogen. Our results indicate that low availability of phosphorus and nitrogen combined with excess organic carbon, is the main factor accounting for relatively low DOC utilization in Imboassica lagoon.

Acknowledgments - This research was supported by grants from the Brazilian Research Council (CNPq), FAPERJ, PETROBRAS to the authors. We thank Dr. David Bisboer and Frederico Meirelles, M.Sc., for their valuable comments on the manuscript.

\section{REFERENCES}

ANESIO, A. M., ABREU, P. C., \& ESTEVES, F. A., 1997, Influence of the hydrological cycle on the bacterioplankton of an impacted clear water Amazonian lake. Microb. Ecol., 34: 66-73.

BAINES, S. B. \& PACE, M.L., 1991, The production of dissolved organic matter by phytoplankton and its importance to bacteria: Patterns across marine and freshwater systems. Limnol. Oceanogr., 36: 1078-1090.

BANO, N., MORAN, M. A., \& HODSON R. E., 1997, Bacterial utilization of dissolved humic substances from a freshwater swamp. Aquat. Microb. Ecol., 12: 233-238.

BENNER, R., OPSAHL S., CHIN-LEO, G., RICHEY, J. E., \& FORSBERG, B. R., 1995, Bacterial carbon metabolism in the Amazon River system. Limnol. Oceanogr., 40: $1262-$ 1270.

BJØRNSEN, P. K., 1986, Automatic determination of bacterioplankton biomass by image analysis. Appl. Environ. Microbiol., 51: 1199-1204.

BOUVY, M., ARFI, R., CECCHI, P., CORBIN, D., PAGANO, M., SAINT-JEAN, L., \& THOMAS, S., 1998, Trophic coupling between bacterial and phytoplanktonic compartments in shallow tropical reservoirs (Ivory Cost, West Africa). Aquat. Microb. Ecol., 15: 25-37.

BRANCO, C. W. C., ESTEVES, F. A., \& KOZLOWSKYSUZUKI, B., 2000, The zooplankton and other limnological features of a coastal lagoon (Lagoa Comprida, Macaé, R.J.) in Brazil. Hydrobiologia, 437: 71-81.

BRATBAK, G., 1985, Bacterial biovolume and biomass estimations. Appl. Environ. Microbiol., 49: 1488-1493.

BRATBAK, G. \& THIGSTAD, T. F., 1985, Phytoplanktonbacteria interactions: an apparent paradox? Analyses of a model system with both competition and commensalism. Mar. Ecol. Prog. Ser, 25: 23-30.

CARLSON, C. A. \& DUCKLOW, H. W., 1996, Growth of bacterioplankton and consumption of dissolved organic carbon in the Sargasso Sea. Aquat. Microb. Ecol., 10: 69-85.

CIMBLERIS, A. C. P. \& KALFF, J., 1998, Planktonic bacterial respiration as a function of $\mathrm{C}: \mathrm{N}: \mathrm{P}$ ratios across temperate lakes. Hydrobiologia, 384: 89-100.

COFFIN, R. B., CONNOLLY, J. P., \& HARRIS P. S., 1993, Availability of dissolved organic carbon to bacterioplankton examined by oxygen utilization. Mar. Ecol. Prog. Ser. 101: 9-22.

COLE, J. J. \& PACE, M. L., 1995., Why measure bacterial production? A reply to the comment by Jahnke and Craven. Limnol. Oceanogr., 40: 441-444.

CURRIE, D. J., 1990, Large-scale variability and interactions among phytoplankton, bacterioplankton and phosphorus. Limnol. Oceanogr., 35: 1437-1455.

DEL GIORGIO, P., BIRD, D. F., PRAIRIE, Y. T., \& PLANAS, D., 1996, Flow cytometric determination of bacterial abundance in lake plankton with the green nucleic acid stain SYTO 13. Limnol. Oceanogr., 41: 783-789.

DEL GIORGIO, P. A., COLE, J. J., \& CIMBLERIS, A., 1997, Respiration rates in bacteria exceed phytoplanton production in unproductive aquatic systems. Nature, 385: 148-151.

DUCKLOW, H. W., 1994, Modeling the microbial food web. Microb. Ecol., 28: 303-319.

ENRÍQUEZ, S., DUARTE, C. M., \& SAND-JENSEN, K., 1993, Patterns in decomposition rate among photosynthetic organisms - the importance of detritus CNP content. Oecologia, 94: 457-471.

ESTEVES, F.A., 1998, Lagoas costeiras: origem, funcionamento e possibilidades de manejo. pp. 63-87 In: F. A. Esteves (ed.), Ecologia das Lagoas Costeiras do Parque Nacional da Restinga de Jurubatiba e do Município de Macaé(RJ), NUPEM-UFRJ, Macaé, Rio de Janeiro, Brazil.

FAGERBAKKE, K., HELDAL, M., \& NORLAND, S., 1996, Content of carbon, nitrogen, oxygen, sulfur and phosphorus in native aquatic and cultured bacteria. Aquat. Microb. Ecol., 10: 15-27.

FARJALLA, V. F., FARIA, B. M., ESTEVES, F. A. \& BOZELLI, R. L., 2001, Bacterial density and biomass, and relations with abiotic factors, in 14 coastal lagoons of Rio de Janeiro State. pp. 65-76 In: B. M. Faria, V. F. Farjalla, \& F. A. Esteves (eds.), Aquatic Microbial Ecology in Brazil, Serie Oecologia Brasiliensis, PPGE-UFRJ, Rio de Janeiro, Brazil.

FARJALLA, V. F., FARIA, B. M., \& ESTEVES, F. A., 2002, The relationship between DOC and planktonic bacteria in tropical coastal lagoons. Arch. Hydrobiol., 156: 97-119.

FRY, J. C., 1990, Direct methods and biomass estimation. Met. Microbio., 22: 41-85.

GOLTERMAN, H. L., CLYMO, R. S., \& OHNSTAD, M. A. M., 1978, Methods of physical and chemical analysis of fresh water. Blackwell Scientific Publishers, Oxford, 214p. 
HEDGES, J. I. \& KEIL, R. G., 1995, Sedimentary organic matter preservation: an assessment and speculative synthesis. Mar. Chem., 49: 81-115.

KIRCHMAN, D. L., SUZUKI, Y., GARSIDE, C., \& DUCKLOW, H. W., 1991, High turnover rates of dissolved organic carbon during a spring phytoplankton bloom. Nature, 352: 612-614.

LE, J., WEHR, J. D., \& CAMPBELL, L., 1994, Uncoupling of bacterioplankton and phytoplankton production in fresh waters is affected by inorganic nutrient limitation. Appl. Environ. Microbiol. 60: 2086-2093.

LINDELL, M. J. \& EDLING, H., 1996, Influence of light on bacterioplankton in a tropical lake. Hydrobiologia, 323: $67-73$.

MACKERETH, F. J. H., HERON, J., \& TALLING, J. F., 1978, Water analysis: some revised methods for limnologists. Freshwater Biological Association, scientific publication $N^{\circ}$. 36, Cumbria and Dorset.

MANN, C. J. \& WETZEL, R. G., 1996. Loading and utilization of dissolved organic carbon from emergent macrophytes. Aquat. Bot., 53: 61-72.

MELO, S., 2001, Fitoplâncton da Lagoa Imboassica (Macaé, RJ, Brazil): flora, estrutura da comunidade e variações especiais e temporais. Ph.D. Dissertation, PPGE-UFRJ, Rio de Janeiro, Brazil, 154p.

MIDDELBOE, M. \& SØNDERGAARD, M., 1993, Bacterial growth yield: seasonal variations and coupling to substrate lability and $\beta$-glucosidase activity. Appl. Environ. Microbiol., 59: 3916-3921.

NEIDHARDT, F. C., INGRAHAM, J. L., \& SCHAECHTER, M., 1990, Physiology of the bacterial cell: a molecular approach. Sinauer Assoc.

NORLAND, S., HELDAL, M., \& TUMYR, O., 1987, On the relation between dry-matter and volume of bacteria. Microb. Ecol., 13: 95-101.

NUSCH, E. A. \& PALME, G., 1975, Biologische methoden für die praxis der gewässeruntersuchung. GWF -Wasser/ Abwasser, 116: 562-565.

PACE, M. L. \& COLE, J. J., 1994, Comparative and experimental approaches to top-down and bottom-up regulation of bacteria. Microb. Ecol., 28: 181-193.

PACE, M. L. \& COLE, J. J., 1996, Regulation of bacteria by resources and predation tested in whole-lake experiments. Limnol. Oceanogr., 41: 1448-1460.

PALMA-SILVA, C., 1999, Ecologia de Macrófitas Aquáticas em uma lagoa costeira sujeita a impactos antrópicos (Lagoa Imboassica, Macaé, RJ). Ph.D. Dissertation, PPGE-UFRJ, Rio de Janeiro, Brazil.

PANOSSO, R. \& ESTEVES, F. A., 1999, Phosphatase activity and plankton dynamics in two tropical coastal lagoons. Arch. Hydrobiol., 146: 341-354.

PERDUE, E. M., 1998, Chemical composition, structure, and metal binding properties. pp. 41-61. In: D. O. Hessen \& L. J. Tranvik (eds.), Aquatic Humic Substances: Ecology and Biogeochemistry. Springer-Verlag.
POMEROY, L. R., SHELDON, J. E., SHELDON, W. M., \& PETERS, F., 1995, Limits to growth and respiration of bacterioplankton in the Gulf of Mexico. Mar. Ecol. Prog. Ser., 117: 259-268.

PORTER, K. G. \& FEIG, Y. S., 1980, The use of DAPI for identifying and counting aquatic microflora. Limnol. Oceanogr., 25: 943-948.

SMITH, D. C. \& AZAM, F., 1992, A simple, economical method for measuring bacterial protein syntesis rates in seawater using ${ }^{3} \mathrm{H}$-leucine. Mar. Microb. Food Webs, 6: 107-114.

SØNDERGAARD, M., 1997, Bacteria and dissolved organic carbon in lakes. pp. 138-161 In: K. Sand-Jensen \& O. Petersen (eds.), Fresh. Biol.: Priorities and Development in Danish research.

SØNDERGAARD, M. \& THEIL-NIELSEN, J., 1997, Bacterial growth efficiency in lakewater cultures. Aquat. Microb. Ecol., 12: 115-122.

THEIL-NIELSEN, J. \& SøNDERGAARD, M., 1998, Bacterial carbon biomass calculated from biovolumes. Arch. Hydrobiol., 141: 195-207.

THINGSTAD,T.F.,HAGSTRÖM,Å.,\&RASSOULZADEGAN, F., 1997, Accumulation of degradable DOC in surface waters: caused by 'malfunctioning' microbial loop? Limnol. Oceanogr., 42: 398-404.

THOMAZ, S. M. \& ESTEVES, F. A., 1997, Bacterial dynamics in periphyton from different regions of a tropical coastal lagoon. Arch. Hydrobiol., 139: 495-507.

TOOLAN, T., 2001, Coulometric carbon-based respiration rates and estimates of bacterioplankton growth efficiencies in Massachusetts Bay. Limnol. Oceanogr., 46: 1298-1308.

TORRÉTON, J-P., BOUVY, M., \& ARFI, R., 1994, Dial fluctuations of bacterial abundance and productivity in a shallow eutrophic tropical lagoon. Arch. Hydrobiol., 131: 79-92.

VADSTEIN, O. \& OLSEN, Y., 1989, Chemical composition and phosphate uptake kinetics of limnetic bacterial communities cultured in chemostats under phosphorus limitation. Limnol. Oceanogr., 34: 939-946.

WANG, L. Z., MILLER, T. D., \& PRISCU, J.C., 1992, Bacterioplankton nutrient deficiency in a eutrophic lake. Arch. Hydrobiol., 125: 423-439.

WATSON, S. W., NOVITSKY, T. J., QUINBY, H. L., \& VALOIS, F. W., 1977, Determination of bacterial number and biomass in marine environment. Appl. Environ. Microbiol., 33: 940-946.

WETZEL, R. G. \& LIKENS, G. E., 1991, Limnological analyses. Springer Verlag, New York, 391p.

ZAR, J. H., 1996. Biostatistical analysis. 3rd Edition, Prentice Hall, 662p.

ZWEIFEL, U. L., WIKNER, J., HAGSTRÖM, Å., LUNDBERG, E., \& NORRMAN, B., 1995, Dynamics of dissolved organic carbon in a coastal ecosystem. Limnol. Oceanogr., 40: 299-305. 